A RCHIWA, BIBLIOTEKI

I MUZEA KOŚCIELNE 110 (2018)

https://doi.org/10.31743/abmk.2018.110.08

MARIA DĘBOWSKA* - LUBLIN

\title{
KSIĄDZ ZYGMUNT CHMIELNICKI - BISKUP ŻYTOMIERSKI CZY KANDYDAT NA BISKUPA POMOCNICZEGO W DIECEZJI LUCKIEJ?
}

Ksiądz Zygmunt Chmielnicki, znana postać przedwojennej diecezji łuckiej ${ }^{1}$, posiada w swojej biografii z okresu II wojny światowej niewyjaśnioną do końca kartę. Jest nią, podnoszona wciąż przez niektórych badaczy, sprawa jego nomina-

* Maria Dębowska - dr hab. historii i archiwistyki; emerytowany pracownik Ośrodka Archiwów, Bibliotek i Muzeów Kościelnych KUL; e-mail: dembo@kul.pl

ORCID 0000-0003-2694-1012

${ }^{1}$ Ksiądz Zygmunt Chmielnicki urodził się 9 XI 1891 r. w Nieświczu k. Łucka w rodzinie Leona i Adeli z Kopelińskich. Gimnazjum ukończył w Łucku. Po otrzymaniu świadectwa dojrzałości zapisał się na Wydział Prawa w Uniwersytecie św. Włodzimierza w Kijowie. W 1914 r. przerwał studia prawnicze i został przyjęty na drugi kurs seminarium duchownego w Żytomierzu. Święcenia kapłańskie otrzymał w 1918 r. w Żytomierzu. Po święceniach sprawował funkcję administratora w Horoszkach, filii parafii w Toporzyszczach (dek. Owrucz). W 1921 r. objął także administrację parafii w Uszomierzu, a rok później został dziekanem dekanatu owruckiego w diecezji żytomierskiej. Po raz pierwszy został aresztowany 6 XI 1923 r. Wolność odzyskał w styczniu 1924 r. Po raz drugi uwięziono go 20 IV 1924 r. W areszcie spędził cały okres Świąt Wielkanocnych. Pod koniec 1924 r. objął duszpasterstwo w parafii p.w. św. Barbary w Berdyczowie. Tam został aresztowany po raz trzeci, 18 V 1926 r. Dnia 19 VII 1926 r. otrzymał wyrok trzyletniego pobytu w łagrze. W sierpniu 1926 r. przebywał już na Wyspach Sołowieckich, skąd przewieziono go do więzienia na Butyrkach w Moskwie. Znalazł się w grupie Polaków odesłanych 3 I 1928 r. do Polski w zamian za aresztowanych szpiegów sowieckich. Wraz z matką zamieszkał w Łucku, gdzie otrzymał we wrześniu 1928 r. stanowisko ojca duchownego w seminarium duchownym na Krasnem. W następnych latach pracował także w Kurii Diecezjalnej i redagował „Życie Katolickie”. W latach trzydziestych był jednym z wykładowców Instytutu Przeszkolenia nawróconych lub nawracających się duchownych prawosławnych; wykładał teologię pasterską. W spisie duchowieństwa diecezji łuckiej z $1942 \mathrm{r}$. figuruje jako jeden z dwóch wikariuszy generalnych. Od 13 VIII 1942 r. był też dziekanem dekanatu łuckiego. Został aresztowany przez Niemców 11 VIII 1943 r. w Łucku; przebywał w więzieniu w Równem do 12 XI tego roku. Ponownie został aresztowany w styczniu 1944 r. i 28 III 1944 r. przewieziony do KL Gross-Rosen, gdzie zmarł 16 IV 1944 r. po skatowaniu go przez obozowego kapo. Jego ciało zostało spalone w krematorium. W 1933 r. został odznaczony godnością kanonika (concionator a festis) Prześwietnej Kapituły Ołyckiej, a 18 V 1942 r. uhonorowany godnością 
cji (czy też konsekracji) na biskupa żytomierskiego. Nie istnieją żadne dokumenty (lub nikt do nich nie dotarł) fakt ten potwierdzające, bądź go negujące. Hipoteza taka została sformułowana jedynie na podstawie przekazów ustnych, które były bardziej pogłoskami niż udokumentowanymi faktami.

Przez długie lata po II wojnie światowej próbowano rozwikłać tę zagadkę. Nie starano się jednak w żaden sposób rozwinąć hipotezy o nominacji czy konsekracji ks. Zygmunta Chmielnickiego na biskupa diecezji żytomierskiej, lecz jedynie podawano to jako fakt, wprawdzie prawie niemożliwy do zweryfikowania, ale fakt. Pierwszym, który taką informację podał do publicznej wiadomości, był ks. Jan Rzymełko CM. W 1944 r. został on przewieziony razem z ks. Chmielnickim z więzienia we Wrocławiu do KL Gross-Rosen:

ze mną przybył do Gross-Rosen ks. biskup Zygmunt Chmielnicki, prekoni-

zowany za wiedzą papieża Piusa XII, biskup żytomierski z diecezji łuckiej²

Tę informację niejako potwierdził ks. Wacław Hipsz (przed drugą wojną światową katecheta we Włodzimierzu Wołyńskim), z tym tylko, że według niego, bp Szelążek ,udzielił sakry Chmielnickiemu już w 1939 r., a wieść o tym fakcie podał do Rzymu"’. Trzeba jednakże wyjaśnić, iż ks. Hipsz opuścił diecezję łucką wkrótce po agresji Związku Sowieckiego na Polskę, a więc nie miał informacji z pierwszej ręki. Powtórzył tylko to, czego księża z diecezji łuckiej starali się dociec po wojnie. Nawiasem mówiąc, nikt nie wspomniał o tym, czy był dopytywany o to po wojnie sam biskup łucki. Należy również dodać, iż inny z więźniów KL Gross-Rosen ks. Julian Rykała nie wspomniał nic o ks. Chmielnickim jako osobie z sakrą biskupią:

Wśród nas znajdował się, starszy wiekiem, wikariusz generalny z Łucka, ksiądz Zygmunt Chmielnicki. Okazałej postawy zewnętrznej, skupiony, pobożny, bardzo zwracał na siebie wzrok łagrowych, toteż był przedmiotem szczególnego prześladowania ${ }^{4}$.

$\mathrm{Z}$ dużym sceptycyzmem podszedł do pogłoski o mianowaniu ks. Chmielnickiego biskupem żytomierskim ks. Marian Sokołowski (do wybuchu II wojny światowej proboszcz parafii katedralnej w Łucku), który po powrocie do Polski w 1945 r. ${ }^{5}$, próbował tę zagadkę rozwikłać. W konkluzji stwierdził:

prałata-scholastyka tejże kapituły, M. Dębowska, L. Popek, Duchowieństwo diecezji luckiej. Ofiary wojny i represji okupantów 1939-1945, Lublin 2010, s. 46-48.

${ }^{2}$ Archiwum Abpa Eugeniusza Baziaka (dalej: ArAEB), Materiały ks. L. Krejczy, t. Ks. Zygmunt Chmielnicki, Ks. Jan Rzymełko CM do kanclerza Kurii Diecezjalnej w Płocku, 11 VI 1948 r. Por. P. Weiser, Ksiądz Zygmunt Chmielnicki 1891-1944, Lublin 2001, s. 52, który powołuje się na „Protokół przesłuchania świadka Jana Rzymełko z dnia 22 marca 1947 roku”, przechowywany w Archiwum Państwowego Muzeum Gross-Rosen, sygn. 14/149/MF.

${ }^{3}$ Tę informację zawarł ks. Hipsz w piśmie do Leona Popka z 30 IV 1988 r., zob. P. Weiser, Ksiadz Zygmunt Chmielnicki, s. 52; por. L. Popek, Dzieje diecezji łuckiej 1925-1939, Lublin 2003, s. 128 (Archiwum Katolickiego Uniwersytetu Lubelskiego Jana Pawła II w Lublinie, sygn. 26830, mps).

${ }^{4}$ J. Rykała, Więźniowie, Heftlingi, Emigranci, Warszawa 1972, s. 117.

${ }^{5}$ Po uderzeniu Związku Sowieckiego na Polskę 17 IX 1939 r. ks. Marian Sokołowski, w latach międzywojennych przetrzymywany w więzieniach sowieckich, opuścił diecezję łucką 7 październi- 
nie jest wykluczone, że w tym czasie mogli być tajemnie konsekrowani biskupi, a ks. Chmielnicki był jak najbardziej odpowiedni do podobnego uhonorowania, wszakże definitywnie pewnej wiadomości o jego biskupstwie nie ma ${ }^{6}$.

Poza zeznaniem i relacją ks. Rzymełki oraz przekazami księży łuckich nie ma żadnych dokumentów potwierdzających fakt nominacji (bądź konsekracji) ks. Chmielnickiego na biskupa diecezji żytomierskiej. Na ten brak dokumentów, o zasadniczym znaczeniu dla rozstrzygnięcia wspomnianej kwestii zwrócił uwagę także R. Dzwonkowski ${ }^{7}$. Mimo to, informacja o tym jest powtarzana do dzisiaj, bez starania się o jakiekolwiek uzasadnienie. Podobne stanowisko, prawdopodobnie w oparciu tylko o przekazy księży Rzymełki i Hipsza, lansuje w swoich publikacjach L. Popek ${ }^{8}$, a za nim inni ${ }^{9}$.

Wprawdzie nie pojawiły się dotychczas jeszcze żadne dokumenty, odnoszące się bezpośrednio do wspomnianego zagadnienia, niemniej jednak, włączenie do obiegu naukowego nowych materiałów archiwalnych oraz publikacji dotyczących Kościoła katolickiego na Wołyniu, pozwala na poddanie krytyce zasygnalizowane tu twierdzenie o tym, jakoby ks. Chmielnicki był biskupem, konsekrowanym przez ordynariusza łuckiego dla Żytomierza.

$\mathrm{Z}$ powodu braku materiałów potwierdzających fakt nominacji (konsekracji) ks. Chmielnickiego na biskupa żytomierskiego, należałoby przyjrzeć się warunkom stworzonym na Wołyniu przez okupanta sowieckiego i postawić pytanie, czy możliwa była takowa nominacja dla ks. Chmielnickiego w czasie pierwszej okupacji sowieckiej? Ksiądz Hipsz twierdził, że nastąpiło to już w 1939 r. Należy

ka tego roku i przedostał się na Węgry. Do 1945 r. przebywał w miejscach internowania żołnierzy polskich, M. Dębowska, L. Popek, Duchowieństwo diecezji łuckiej. Ofiary wojny i represji okupantów 1939-1945, Lublin 2010, s. 137.

${ }^{6}$ ArAEB, Materiały ks. L. Krejczy, t. Ks. Zygmunt Chmielnicki, Relacja ks. Mariana Sokołowskiego (kserokopia).

${ }^{7}$ R. Dzwonkowski, Losy duchowieństwa katolickiego w ZSSR 1917-1939. Martyrologium, Lublin 1998, s. 190: „Wg relacji grupy księży, kolegów z diec. łuckiej, był biskupem nominatem żytomierskim, na co jednak brak jakichkolwiek dowodów. Istnieje również pogłoska o jego konsekracji biskupiej podczas okupacji niem., dokonanej przez ordynariusza łuckiego, Adolfa Szelążka (18651950), o czym ten ostatni miał późn. powiadomić Stolicę Apost. Jest ona bezpodstawna, gdyż brak jest jej potwierdzenia w dokumentach Stolicy Apost. z okresu II wojny świat., zawierających m.in. przesłaną do Rzymu relację bpa A. Szelążka”.

${ }^{8}$ „Na biskupa nominata żytomierskiego potajemnie konsekrował [bp Szelążek - M.D.] ks. prałata Zygmunta Chmielnickiego, o czym poinformował Watykan”, L. Popek, Diecezja tucka, w: Życie religijne w Polsce pod okupacja 1939-1945. Metropolie wileńska i lwowska, zakony, red. Z. Zieliński, Katowice 1992, s. 499; tenże, Diecezja tucka w okresie międzywojennym i podczas II wojny światowej (1918-1944), w: Polacy i Kościót rzymskokatolicki na Wotyniu w latach 19181997, red. L. Popek, Lublin 1999, s. 41; tenże, „Dzieje diecezji łuckiej 1925-1939”, s. 128; tenże, Straty Kościoła rzymskokatolickiego na Wołyniu w latach 1939-1945, w: Polskie Państwo Podziemne na Wolyniu w latach 1939-1944, red. M. Sawczuk, L. Popek, Sandomierz 2006, s. 102.

${ }^{9}$ Zob. np. Martyrologium duchowieństwa - Polska. Dane osobowe, w: http://www.swzygmunt. knc.pl/MARTYROLOGIUM/POLISHRELIGIOUS/vPOLISH/HTMs/POLISHRELIGIOUSmartyr0305.htm (dostęp: 24.07.2018) informacja o ks. Zygmuncie Chmielnickim - „biskup nominat żytomierski (sakry miał udzielić bp Szelążek, ale nie ma dowodów w dokumentacji)”. 
podkreślić, że okupant sowiecki, po zajęciu ziem wschodnich II Rzeczypospolitej, nie zlikwidował kordonu granicznego, który oddzielał Związek Sowiecki od Polski przed wybuchem wojny w 1939 r. Uczyniono to nie dlatego, że mieszkańcy ziem wschodnich II RP ruszyliby masowo do „raju sowieckiego”, ale dlatego, aby obywatele Związku Sowieckiego nie zdołali poznać zbyt wcześnie „wolnego świata". Wspomniana granica przestała istnieć dopiero po uderzeniu Niemiec na Związek Sowiecki w czerwcu $1941 \mathrm{r}$. W związku z tym, należy zadać pytanie o celowość takiego działania podjętego jakoby przez biskupa łuckiego w stosunku do innej diecezji, w dodatku niedostępnej, bo pozostającej poza kordonem granicznym mniej lub bardziej pilnie strzeżonym. Nawet jeśli informacja o nominacji biskupa dla diecezji żytomierskiej byłaby prawdziwa, to i tak dziwnym się wydaje, że biskup łucki pominął diecezję kamieniecką, która znajdowała się w podobnej sytuacji.

Nieuprawnione jest na pewno uznawanie za pewnik, że „między Szelążkiem i kurią a Rzymem szła w czasie wojny korespondencja" ${ }^{10}$. Podobnie rzecz się ma z nadużywaniem twierdzenia, jakoby bp Szelążek o niektórych swoich działaniach informował Stolicę Apostolską. Stwarza to wrażenie, że przeszkody w komunikowaniu się z Watykanem może istniały, ale pokonanie ich nie stwarzało poważniejszych trudności ${ }^{11}$. Kluczowe $\mathrm{w}$ tym względzie jest zeznanie bpa Szelążka, podczas jego przesłuchania w Kijowie w 1945 r., o tym, iż w czasie pierwszej okupacji sowieckiej nie wysyłał on żadnych pism do Watykanu' ${ }^{12}$. Musi więc upaść - przytoczona powyżej - informacja ks. Hipsza, lansowana przez L. Popka, że bp Szelążek ,udzielił sakry Chmielnickiemu już w 1939 r., a wieść o tym fakcie podał do Rzymu".

Ważne jest jeszcze jedno wydarzenie, w oparciu o które można poddać w wątpliwość omawiany tutaj przekaz o ks. Chmielnickim jako biskupie żytomierskim. Wkrótce po ataku Niemiec na Związek Sowiecki i zniesieniu kordonu granicznego, oddzielającego przedwojenne państwo polskie od ZSRS, na tereny diecezji żytomierskiej i kamienieckiej, do pracy duszpasterskiej, wyruszyło z diecezji łuckiej kilku księży. Ordynariusz łucki zamierzał jednak nadać duszpasterstwu we wspomnianych diecezjach jakieś formy organizacyjne. Nie chciał i nie mógł tego uczynić bez porozumienia z nowymi władzami okupacyjnymi. Wysłał więc do Żytomierza w listopadzie 1941 r. na rozmowy w tej sprawie dwóch swoich wysłanników, księży Jana Zagórskiego i Władysława Bukowińskiego ${ }^{13}$. Pismem

${ }^{10}$ Weiser, Ksiadz Zygmunt Chmielnicki, s. 52, przyp. 4. Autor ten oparł swoje przekonanie o przekaz listu Domenico Tardiniego (podał błędnie nazwisko tego prałata: Cardini) do ks. Jana Szycha z 16 XI 1945 r. Jednak treść listu dowodzi czegoś wręcz przeciwnego niż twierdzenie tego autora, zob. M. Dębowska, Nadzwyczajne uprawnienia dla biskupów diecezjalnych na terenach RP zajętych przez wojska radzieckie w 1939 roku, „Archiwa, Biblioteki i Muzea Kościelne”, 78 (2002) s. 56-57.

${ }^{11}$ M. Dębowska, Kościół katolicki na Wolyniu w warunkach okupacji 1939-1945, Rzeszów 2008, s. 98-106.

${ }^{12}$ Archiwum Instytutu Pamięci Narodowej w Warszawie, sygn. 177/559/1/1, Protokół z przesłuchania bpa A. Szelążka z 20 III 1945 r.

${ }^{13}$ Dokumenty dotyczące misji księży Jana Zagórskiego i Władysława Bukowińskiego zob. Reaktywowanie duszpasterstwa $w$ diecezjach żytomierskiej i kamienieckiej. Materiały źródłowe Kurii Diecezjalnej w Lucku 1941-1945, oprac. M. Dębowska, Rzeszów 2010, s. 33-51. 
z 8 listopada tego roku bp Szelążek powierzył ks. Zagórskiemu ,zarząd diecezji żytomierskiej do czasu naznaczenia przez Stolicę Apostolską administratora tej diecezji"14. I tu należy postawić dwa pytania: pierwsze, gdyby ks. Chmielnicki był biskupem żytomierskim, czy nie byłoby właściwsze, że to on właśnie powinien był podjąc się rozmów w sprawach „swojej przecież diecezji”? I drugie - czy zarząd diecezji żytomierskiej zostałby powierzony ks. Zagórskiemu, gdyby biskupem był ks. Chmielnicki?

Nie powinno być tu pominięte również inne przedsięwzięcie bpa Szelążka, mające związek z omawianym tu zagadnieniem. Latem 1944 r., już po ponownym zajęciu Wołynia przez Armię Czerwoną, bp Szelążek wydelegował kilku swoich księży do pracy duszpasterskiej na wschodnim Wołyniu oraz Podolu. Celem łatwiejszego rozwiązywania rodzących się problemów (bez konieczności ciągłego odwoływania się do biskupa w Łucku, co było skomplikowane ze względu na warunki wojenne) ordynariusz łucki wyznaczył tymczasowymi administratorami: diecezji żytomierskiej - ks. Bronisława Drzepeckiego, a diecezji kamienieckiej ks. Adolfa Kukuruzińskiego (obydwaj posiadali stopnie naukowe doktora). Jesienią tego roku (1944) napisał pisma do papieża z prośbą o wyniesienie do godności biskupiej wspomnianych dwóch duchownych ${ }^{15}$.

W związku z powyższymi informacjami, nasuwa się oczywiste pytanie: czy bp Szelążek prosiłby o nominację dla ks. Drzepeckiego na biskupa żytomierskiego, gdyby kilka lat wcześniej już nominował (czy konsekrował) kogoś innego na to stanowisko? Wydaje się, że prośba o nominację dla ks. Drzepeckiego jest rozstrzygająca $\mathrm{w}$ omawianej tu kwestii - ks. Zygmunt Chmielnicki nigdy nie był nominowany (ani tym bardziej konsekrowany) na biskupa diecezji żytomierskiej! I nie ma tu żadnego znaczenia fakt, że poniósł on śmierć w Gross-Rosen już w kwietniu 1944 r., gdyż wiadomość o tym do końca wojny nie dotarła do Łucka. A więc w momencie pisania prośby do papieża bp Szelążek nie wiedział o zgonie ks. Chmielnickiego. W związku z wyznaczeniem ks. Drzepeckiego zarządcą diecezji żytomierskiej należy pamiętać, iż ks. Jan Zagórski - ustanowiony do objęcia tego stanowiska w $1941 \mathrm{r}$. - zmarł 11 lutego 1942 r.

Jest wręcz nieprawdopodobne, aby ordynariusz łucki konsekrował biskupa dla innej diecezji bez jego uprzedniej prekonizacji. Na pewno bp Szelążek nie miał takich uprawnień. Nawet nadzwyczajne pełnomocnictwa z 1939 r. nie dawały mu takiego prawa. Natomiast takie działania, jak wyznaczenie rządców (bez możliwości udzielenia im sakry biskupiej!) dla diecezji żytomierskiej i kamienieckiej, mógł biskup łucki podjąć na mocy wspomnianych specjalnych pełnomocnictw, których udzielił papież Pius XII, 29 listopada 1939 r., wszystkim biskupom tych

14 Tamże, s. 42.

${ }^{15}$ Dębowska, Kościół katolicki na Wołyniu, s. 314; B.E. Karwowska, Proces i uwięzienie ks. biskupa Adolfa Piotra Szelążka, w: Kościót w obliczu totalitaryzmów, red. W. Polak i in., Toruń 2010, s. 160-161: „Podczas rewizji u Ks. Bpa Adolfa Piotra Szelążka znaleziono ważne dokumenty, związane z jego duszpasterską posługą, między innymi korespondencję z papieżem i nuncjuszem apostolskim w Berlinie. Były to następujące pisma: [...] 3. Listy Biskupa Szelążka do papieża Piusa XII, dotyczące administratorów diecezji kamienieckiej i żytomierskiej. W tych samych listach Bp Szelążek prosi o wyniesienie ks. A. Kukuruzińskiego i ks. B. Drzepeckiego do godności biskupiej”. 
diecezji, które znalazły się we wrześniu 1939 r. (lub w późniejszych miesiącach) pod okupacją sowiecką ${ }^{16}$. Te pełnomocnictwa odnosiły się przede wszystkim do własnej diecezji każdego z biskupów. Jednakże istnieją podstawy do tego, aby sądzić, że bp Szelążek posłużył się nimi w celu reaktywowania struktur kościelnych w diecezjach żytomierskiej i kamienieckiej. Na minucie pisma nominacyjnego dla ks. Bronisława Drzepeckiego - sporządzonego własnoręcznie przez ordynariusza łuckiego - dopisał on zalecenie dla urzędników kurialnych, aby umożliwili zapoznanie się „ks. kanonikowi Drzepeckiemu z tymi rozporządzeniami Stolicy Ap. (facultates extraordinariae), które Ordynariuszom Diecezji zostały wydane z okazji wojny"17. Wywody powyższe znajdują potwierdzenie w słowach ks. Jana Szycha (kanclerza Kurii Diecezjalnej w Łucku), zawartych w sprawozdaniu dla Stolicy Apostolskiej z sierpnia 1945 r.: ,władza wszystkich tych księży oparta była na Facultates Speciales przyznanych przez Stolicę Apostolską na tereny sowieckie od samego początku wojny"18.

Niemniej jednak, po odrzuceniu twierdzenia - jako nieprawdopodobnego że ks. Zygmunt Chmielnicki był „biskupem nominatem żytomierskim”, należy zastanowić się nad tym, co mogło oznaczać w odniesieniu do tego duchownego stwierdzenie żandarma w KL Gross-Rosen: „Ich führe Ihnen ihren Bischof”19.

W chwili wybuchu drugiej wojny światowej w zarządzaniu diecezją wspierał bpa Szelążka biskup pomocniczy Stefan Walczykiewicz, który był jednocześnie wikariuszem generalnym in spiritualibus. W łuckiej Kapitule Katedralnej posiadał godność prałata archidiakona. Zmarł on 11 maja 1940 r. i pochowany został na cmentarzu w Łucku.

Do Watykanu, najprawdopodobniej jeszcze w roku śmierci bpa Walczykiewicza, dotarła wiadomość o tym fakcie; informatorem nie był z pewnością ordynariusz łucki. Oczekiwano więc zapewne, że bp Szelążek zgłosi nazwisko (lub nazwiska) kandydata na to stanowisko. Biskup Szelążek miał świadomość konieczności uczynienia tego kroku. Wiedział także z pewnością o niepokoju Stolicy Apostolskiej, która naciskała w tym względzie na metropolitę lwowskiego abp. Bolesława Twardowskiego (,Velis quaeso, data occasione eundem Exc.mum Episcopum Luceoriensem certiorem facere Summum Pontificem paratum esse eidem Auxiliarem vel Coadiutorem cum iure successionis dare. Quapropter tu vel ipse Exc.mus Szelazek nomina quorundam candidatorum quoque modo Sanctae Sedi proferre contendite" ${ }^{20}$ ). Wydaje się, że bp Szelążek został poinformowany przez

${ }^{16}$ Dębowska, Nadzwyczajne uprawnienia, s. 45-55.

${ }^{17}$ Taż, Kościót katolicki na Wotyniu, s. 317.

${ }^{18}$ Centralne Archiwum Polonii w Orchard Lake (USA), sygn. 1141, Ks. Jan Szych, Stan diecezji łuckiej 17 IX 1939 r. - 7 VIII 1945 r., k. 5.

${ }^{19}$ Informacja ta pochodzi od ks. Tadeusza Szerzysko CM, którą przytoczył w swojej relacji ks. Marian Sokołowski, a próbował znaleźć źródło jej pochodzenia i zastanawiał się nad wynikającymi $\mathrm{z}$ tego konsekwencjami autor biografii ks. Chmielnickiego, P. Weiser, Ksiądz Zygmunt Chmielnicki, s. 56. Nie można wykluczyć również tego, że żandarm obozowy użył prześmiewczo tego określenia, zob. tenże, s. 56: „Ta kpina szybko rozniosła się po obozie”.

${ }^{20}$ Kardynał Luigi Maglione do abpa Bolesława Twardowskiego, 6 II 1941 r., Actes et documents du Saint Siège relatifs à la seconde guerre mondiale, vol. 3: Le Saint Siège et la situation religieuse en Pologne et dans les pays balts 1939-1945, Città del Vaticano 1967, s. 369. 
metropolitę lwowskiego o stanowisku papieża ${ }^{21}$, który chciał przedstawionego sobie kandydata mianować nawet koadiutorem cum iure successionis, ze względu na podeszły już wiek ówczesnego ordynariusza łuckiego. Jest wprost nieprawdopodobne, aby bp Szelążek nie zareagował na polecenie Watykanu w tej sprawie. Niestety, ani w zachowanych materiałach archiwalnych, ani we wspomnieniach księży z diecezji łuckiej nie ma najmniejszej wzmianki na temat działań podjętych przez bpa Szelążka, co nie jest dziwne, gdyż tego typu sprawy nie mogły przedostawać się na forum publiczne.

Można domniemywać, iż bp Szelążek wyznaczył kandydata na stanowisko swojego pomocnika. Mógł być nim tylko ks. Zygmunt Chmielnicki. Możliwość taką, iż ks. Chmielnicki był kandydatem bpa Szelążka na sufragana łuckiego rozważał już P, Weiser, autor biografii tego duchownego ${ }^{22}$. Wskazał on na informację, że w sierpniu 1943 r. informator Okręgu Wołyńskiego Biura Informacji i Propagandy Delegatury Rządu na Kraj przekazał do centrali w Warszawie wiadomość o aresztowaniu przez gestapo w Lucku ks. Zygmunta Chmielnickiego, który ,pełnił w Łucku urząd sufragana" ${ }^{23}$. Jednakże autor biografii wspomnianego księdza nie oddał dokładnie treści przekazu informatora BIP. W rzeczywistości Jadwiga Zaleska („Kora”, „Zofia Sujkowska”), szef BIP Okręgu AK Wołyń, w raporcie z 20 sierpnia 1943 r., poinformowała o aresztowaniu w Łucku przez gestapo ks. Chmielnickiego, który był ,przewidywany w swoim czasie na sufragana"24. Pomiędzy stwierdzeniami ,,pełnił w Łucku urząd sufragana” a „był przewidywany na sufragana" jest znaczna różnica. Biografowi ks. Chmielnickiego zabrakło chyba jednak wystarczającej wiedzy ${ }^{25}$, by swoją hipotezę rozwinąć i zakończyć jasną konkluzją, gdyż wszystko wskazuje na to, że zasygnalizowana przez niego ewentualność jest najbliższa prawdy.

$\mathrm{Na}$ wyjątkową rolę ks. Chmielnickiego w Łucku wskazują świadkowie tamtych czasów. Ksiądz Edmund Domański, który w listopadzie 1941 r. powrócił do diecezji łuckiej z Generalnego Gubernatorstwa wspominał:

gdy zajechałem do Łucka, szczególnie zatroszczył się mną ks. Chmielnicki, jak żaden z księży, o wszystko się pytał, wiele mi serca poświęcił, w odróżnieniu od innych księży, którzy okazali wielką obojętność. Wówczas przyszła mi myśl, czy ks. Chmielnicki nie jest może biskupem ${ }^{26}$.

Jeśli przyjmiemy, że kandydatem bpa Szelążka na stanowisko sufragana w Łucku był ks. Chmielnicki, należałoby postawić pytanie, kiedy ordynariusz łucki podjął tę decyzję. Bardzo możliwe, że stało się to już w drugiej połowie $1940 \mathrm{r}$. (bp Walczykiewicz zmarł 11 maja 1940 r.), gdyż pierwszą połowę następnego

${ }^{21}$ Kontakty z rządcami diecezji, oddzielonych kordonem granicznym. były w miarę częste. Wydaje się jednak, że znacznie łatwiej przekazywane były przez kordon graniczny wiadomości do bpa Szelążka niż odwrotnie.

${ }^{22}$ Weiser, Ksiądz Zygmunt Chmielnicki, s. 52-53.

${ }^{23}$ Tamże, s. 52.

${ }^{24}$ Dębowska, Kościół katolicki na Wolyniu, s. 96.

${ }^{25} \mathrm{Na}$ przykład, według niego bp Tomaka został mianowany sufraganem dla Łucka wkrótce po śmierci bpa Walczykiewicza, P. Weiser, Ksiądz Zygmunt Chmielnicki, s. 52.

${ }^{26}$ Cyt. za: Dębowska, Kościół katolicki na Wołyniu, s. 96. 
roku ks. Chmielnicki spędził w klinice chirurgicznej we Lwowie, gdzie usunięto mu nerkę (najprawdopodobniej), lub po jego powrocie do Łucka w czerwcu $1941 \mathrm{r}$. Do pierwszych miesięcy 1941 r. pismo z nazwiskami kandydatów na biskupa pomocniczego w Łucku na pewno nie dotarło do Watykanu, ponieważ kardynał Luigi Maglione wysłał do metropolity lwowskiego list w tej sprawie $\mathrm{z}$ datą 6 lutego 1941 r. Można przyjąć, że bp Szelążek mógł wprawdzie podjąć decyzję w drugiej połowie 1940 r., ale pisma $\mathrm{z}$ nazwiskiem kandydata na sufragana nie wysłał do Watykanu aż do końca pierwszej okupacji sowieckiej, gdyż - jak już była o tym mowa wcześniej - ordynariusz łucki w czasie pierwszej okupacji sowieckiej nie wysyłał żadnych pism do Stolicy Apostolskiej.

Przyjąć więc można, że pismo bpa Szelążka z nazwiskiem (lub nazwiskami) kandydata (kandydatów) na stanowisko biskupa pomocniczego w Łucku zostało wyekspediowane do Watykanu w pierwszych miesiącach okupacji niemieckiej (być może jeszcze w 1941 r.). Zapewne posłużono się specjalnym kurierem, gdyż tylko ten sposób dawał jaką taką pewność dotarcia przesyłki do adresata. Mijały jednak miesiące, a nawet lata, a do Łucka nie dotarł żaden dokument nominacyjny. W międzyczasie biskup łucki otrzymał list gratulacyjny od papieża (z 7 października 1943 r.) z okazji dwudziestopięciolecia jego sakry biskupiej (sakrę biskupią otrzymał bp Szelążek 17 listopada 1918 r.) ${ }^{27}$. Prosekretarz Stanu Stolicy Apostolskiej Domenico Tardini, zapytujący ks. Jana Szycha (kanclerza Kurii Diecezjalnej w Łucku) w listopadzie 1945 r., czy wspomniany list gratulacyjny papieża dotarł do adresata ${ }^{28}$, nawet słowem nie wspomniał o jakiejkolwiek, otrzymanej wcześniej, korespondencji od biskupa łuckiego. Pytanie zadane przez Domenico Tardiniego dowodzi, że do końca II wojny światowej żadnego pisma od biskupa łuckiego Watykan nie otrzymał. Działania Stolicy Apostolskiej, podjęte na początku 1944 r. odnośnie do diecezji łuckiej również na to wskazują.

Stanowisko biskupa pomocniczego w Łucku było nieobsadzone aż do $1944 \mathrm{r}$. Wtedy bowiem, brak jakichkolwiek wiadomości od biskupa łuckiego zdopingował Stolicę Apostolską do działania. Zasadniczym bodźcem były alarmistyczne wieści o diecezji łuckiej przekazane przez biskupa katowickiego Stanisława Adamskiego. W Watykanie obawiano się nawet, że stolica biskupia w Łucku może wakować, zważywszy na to, iż bp Szelążek 30 lipca 1944 r. miał skończyć już 79 lat. Nie czekając już dłużej, papież w styczniu 1944 r. podjął decyzję o wyznaczeniu administratora apostolskiego dla diecezji łuckiej. W Watykanie przygotowano nominację na to stanowisko dla sufragana przemyskiego, bpa Wojciecha Tomaki, o czym zawiadomił nuncjusza berlińskiego Cesare Orsenigo kardynał Luigi Ma-

${ }^{27}$ Domenico Tardini do ks. Jana Szycha, 16 XI 1945 r.: „W okresie tych ciężkich doświadczeń Stolica Apostolska starała się, w miarę swoich możliwości, ulżyć w cierpieniach, niestety, nie zawsze z pozytywnym skutkiem. Jedną z oznak takiej troski Ojca Świętego jest list, który zechciał On wysłać w dniu 7 października 1943 r. do Jego Ekscelencji biskupa łuckiego z okazji dwudziestej piątej rocznicy otrzymania sakry biskupiej”. Dębowska, Nadzwyczajne uprawnienia, s. 57.

${ }^{28}$ Ks. Jan Szych do Domenico Tardiniego, 30 V 1946 r.: „Jego Ekscelencja Biskup A. Szelążek natychmiast przygotował serdeczną odpowiedź, której jednakże nie mógł wysłać, ponieważ byliśmy pozbawieni jakiejkolwiek łączności ze światem zewnętrznym. Na dodatek, w czasie rewizji bolszewicy znaleźli i zabrali tę odpowiedź i włączyli ją do akt Biskupa w Kijowie”. Tamże, s. 59. 
glione pismem z 31 stycznia 1944 r. ${ }^{29}$ Natomiast bp Wojciech Tomaka otrzymał pismo nuncjusza, wysłane $\mathrm{z}$ datą 8 lutego, już w trzy dni później, to znaczy 11 lutego i jeszcze tego samego dnia napisał odpowiedź. Poinformował w nim nuncjusza, iż sprawę swojej nominacji natychmiast przedyskutował $\mathrm{z}$ ordynariuszem przemyskim Franciszkiem Bardą i obydwaj doszli do wniosku, iż polecenie papieża jest niewykonalne ${ }^{30}$. Jednocześnie bp Tomaka częściowo uspokoił Watykan informacją, że bp Szelążek żyje.

Sufragan przemyski wysłał do ordynariusza łuckiego pismo z wiadomością o rozporząazzeniu papieża ${ }^{31}$. Ten odpisał, że nie potrzebuje jego pomocy, gdyż radzi sobie sam w zarządzaniu diecezją łucką ${ }^{32}$. Można domniemywać, iż bp Szelążek takim obrotem sprawy został zaskoczony; prawdopodobnie wtedy uświadomił sobie, że jego pismo z kandydaturą na biskupa pomocniczego nie dotarło do Watykanu. Niemniej jednak, poprosił papieża o zmianę decyzji. $Z$ wielkim prawdopodobieństwem można domniemywać, że bp Szelążek pragnął to stanowisko zachować dla ks. Chmielnickiego, którego losu nie mógł przecież wówczas przewidzieć. Pismo wyjaśniające tę kwestię napisał (jak dotychczas nie jest znana jego treść) i zamierzał wysłać do Watykanu. Jednakże, zarówno to pismo, jak i kilka innych, nie opuściło mieszkania biskupa do pierwszych dni 1945 r. i zostało przejęte przez $\mathrm{NKGB}^{33}$ w czasie aresztowania bpa Szelążka w nocy z 3 na 4 stycznia tego roku ${ }^{34}$.

Pismo zawiadamiające o wytypowaniu kandydata na sufragana bp Szelążek być może napisał i przekazał - najprawdopodobniej zaufanemu kurierowi - celem dostarczenia go do Rzymu. Istnieje duże prawdopodobieństwo, że pismo bpa Szelążka mogło zostać przejęte przez Niemców i dołączone do akt ks. Chmielnickiego, gdyż

razem z więźniami przywożono do obozu dokumenty policyjne z danymi osobowymi, stwierdzeniem wyroku albo opisem przestępstwa, jakiego dopuścił się skazaniec. Na tej podstawie przyznawano kategorię i oznaczenie, czyli winkiel. Urzędnicy policyjni mogli dodatkowo umieścić adnotacje w rodzaju: »skierować do robót wyniszczających« albo »powrót więźnia niepożądany $\ll^{35}$.

${ }^{29}$ Actes et documents, s. 849. Zagadnienie to wyczerpująco przedstawił T. Śliwa, Wojenna „,misja” ks. bp. Tomaki, „Niedziela” (wydanie przemyskie), (1997) nr 47, s. III-IV; nr 48, s. III; nr 49 , s. II.

${ }^{30}$ „Re cum Excell. Episcopo Fr. Barda Ordinario Premisliensi Latinorum discussa, non solum moralem, sed paene phisicam invenio impossibilitatem exequendi benignissimi mandati Apostolicae Sedis", Actes et documents, s. 855.

${ }^{31} \mathrm{~W}$ jednym z archiwów rosyjskich są przechowywane dwa pisma bpa Tomaki do bpa Szelążka. Dostęp do nich na razie jest niemożliwy. Informację o poleceniu papieża zawierał list bpa Tomaki z września 1944 r., Dębowska, Kościót katolicki na Wołyniu, s. 94; Karwowska, Proces i uwięzienie ks. biskupa Adolfa Piotra Szelązka, s. 161.

${ }^{32}$ List do Przemyśla zawiozła - specjalnie w tym celu wydelegowana - jedna z benedyktynek misjonarek. Dębowska, Kościót katolicki na Wotyniu, s. 94.

${ }^{33}$ NKGB - Narodnyj Komissariat Gosudarstwiennoj Biezopasnosti (Ludowy Komisariat Bezpieczeństwa Państwowego).

${ }^{34}$ Dębowska, Kościół katolicki na Wotyniu, s. 94; zob. także Karwowska, Proces i uwięzienie ks. biskupa Adolfa Piotra Szelążka, s. 161.

${ }^{35}$ Weiser, Ksiądz Zygmunt Chmielnicki, s. 56. 
Być może, dlatego tak łatwo oprawcy w KL Gross-Rosen szermowali tytułem „biskup” w odniesieniu do ks. Chmielnickiego. Jednakże do tej pory nikomu nie udało się natrafić na najmniejszy ślad takiego pisma. Niemcy, którzy na okupowanych terytoriach likwidowali elity społeczeństwa polskiego, a do nich należała hierarchia Kościoła katolickiego, nie mogli dopuścić do tego, by ktokolwiek został nominowany na biskupa bez ich wiedzy ${ }^{36}$. Dlatego też wydaje się bardzo prawdopodobne to, że przechwyciwszy pismo z kandydaturą ks. Chmielnickiego na sufragana łuckiego, przeznaczyli tego duchownego do likwidacji. Wyjątkowo brutalne traktowanie ks. Chmielnickiego przez kapo obozowych, po przewiezieniu go do Gross-Rosen, wskazuje na to, że znalazł się on tam z wyrokiem śmierci ${ }^{37}$.

$\mathrm{W}$ testamencie ks. Chmielnickiego z 25 stycznia $1941 \mathrm{r} .{ }^{38}$ zapisane są rozporządzenia odnoszące się do jego pogrzebu i miejsca pochówku w razie śmierci. Tymczasem los sprawił, że zmarł on nie we Lwowie w 1941 r., ale w trzy lata później, w obozie koncentracyjnym i nie ma własnego grobu, gdyż jego ciało zostało spalone w piecu krematoryjnym ${ }^{39}$. Ze względu na śmierć ks. Chmielnickiego oraz włączenie kresów wschodnich II Rzeczypospolitej (w tym całego obszaru diecezji łuckiej) do Związku Sowieckiego, ze wszystkimi tego konsekwencjami, po zakończeniu II wojny światowej bp Szelążek nie kontynuował już starań o nominację biskupa pomocniczego w Łucku, gdyż stały się one bezprzedmiotowe.

\section{BIBLIOGRAFIA}

\section{Źródła rękopiśmienne}

Archiwum Abpa Eugeniusza Baziaka

Materiały ks. Leona Krejczy

Archiwum Instytutu Pamięci Narodowej w Warszawie

Protokoły przesłuchań bpa Adolfa Piotra Szelążka

Centralne Archiwum Polonii w Orchard Lake (USA)

sygn. 1141, Ks. Jan Szych, Stan diecezji łuckiej 17 IX 1939 r. - 7 VIII 1945 r.

${ }^{36}$ P. Blet, Pius XII i druga wojna światowa w tajnych archiwach watykańskich, Katowice 2000, s. 123 - „W nocie z 29 sierpnia 1941 r. ambasador von Bergen przedstawił prośbę, aby o wszystkich nominacjach kościelnych na ważne stanowiska w regionach przyłączonych lub okupowanych był powiadamiany najpierw Berlin. Prośba dotyczyła biskupów rezydencjalnych, koadiutorów z prawem następstwa, prelati nullius, administratorów apostolskich, wikariuszy kapitularnych oraz wszystkich, którzy mieli równorzędne funkcje w kierowaniu diecezjami”.

${ }^{37}$ Weiser, Ksiądz Zygmunt Chmielnicki, s. 60-61.

${ }_{38}$ M. Dębowska, Testament ks. Zygmunta Chmielnickiego (1891-1944), kapłana diecezji tuckiej, „Wołanie z Wołynia”, 15 (2009) nr 2, s. 13-18.

${ }^{39}$ Kiedy ciało ks. Chmielnickiego leżało już na wózku lub taczkach, przed odwiezieniem go do krematorium ks. Jan Kąkol, wychowanek ks. Chmielnickiego z seminarium łuckiego, „pocałował jego stopy".Weiser, Ksiądz Zygmunt Chmielnicki, s. 65. 


\section{Źródła drukowane}

Actes et documents du Saint Siège relatifs à la seconde guerre mondiale, vol. 3: Le Saint Siège et la situation religieuse en Pologne et dans les pays balts 1939-1945, Città del Vaticano 1967.

Dębowska Maria, Nadzwyczajne uprawnienia dla biskupów diecezjalnych na terenach RP zajętych przez wojska radzieckie w 1939 roku, „Archiwa, Biblioteki i Muzea Kościelne", 78 (2002) s. 41-64.

Dębowska Maria, Testament ks. Zygmunta Chmielnickiego (1891-1944), kapłana diecezji tuckiej, „Wołanie z Wołynia”, 15 (2009) nr 2, s. 13-18.

Reaktywowanie duszpasterstwa $w$ diecezjach żytomierskiej i kamienieckiej. Materiaty źródłowe Kurii Diecezjalnej w Łucku 1941-1945, oprac. Maria Dębowska, Rzeszów 2010.

\section{Opracowania}

Blet Pierre, Pius XII i druga wojna światowa $w$ tajnych archiwach watykańskich, Katowice 2000.

Dębowska Maria, Kościót katolicki na Wotyniu w warunkach okupacji 1939-1945, Rzeszów 2008.

Dębowska Maria, Popek Leon, Duchowieństwo diecezji tuckiej. Ofiary wojny i represji okupantów 1939-1945, Lublin 2010.

Dzwonkowski Roman, Losy duchowieństwa katolickiego w ZSSR 1917-1939. Martyrologium, Lublin 1998.

Karwowska Beniamina Elżbieta, Proces $i$ uwięzienie ks. biskupa Adolfa Piotra Szelażka, w: Kościół w obliczu totalitaryzmów, red. Wojciech Polak i in., Torun 2010, s. 158167.

Popek Leon, Diecezja łucka, w: Życie religijne w Polsce pod okupacją 1939-1945. Metropolie wileńska i lwowska, zakony, red. Zygmunt Zieliński, Katowice 1992.

Popek Leon, Diecezja tucka $w$ okresie międzywojennym i podczas II wojny światowej (1918-1944), w: Polacy i Kościót rzymskokatolicki na Wołyniu w latach 1918-1997, red. Leon Popek, Lublin 1999.

Popek Leon, Straty Kościoła rzymskokatolickiego na Wołyniu w latach 1939-1945, w: Polskie Państwo Podziemne na Wolyniu w latach 1939-1944, red. Mieczysław Sawczuk, Leon Popek, Sandomierz 2006.

Rykała Julian, Więźniowie, Heftlingi, Emigranci, Warszawa 1972.

Śliwa Tadeusz, Wojenna „misja” ks. bp. Tomaki, „Niedziela” (wydanie przemyskie), 1997, nr 47-49.

Weiser Piotr, Ksiadz Zygmunt Chmielnicki 1891-1944, Lublin 2001. 